\title{
A Rare Case of Transradial Coronary Angiography Resulting in Arteriovenous Fistula
}

\author{
Ahmad Alshatti, Hussain Alzayer and JD Shwalm* \\ The Population Health Research Institute, McMaster University, Canada
}

Submission: March 04, 2017; Published: March 23, 2017

*Corresponding author: JD Schwalm, The Population Health Research Institute, McMaster University, Hamilton Health Sciences, DBCVSRI, C3108, 237 Barton Street East, Hamilton, ON L8L 2X2, Canada, Fax: 905-577-1474; Tel: 905-577-1423; Email: Schwalj@mcmaster.ca

\begin{abstract}
A 79-year-old male presented with chest pain and electrocardiographic evidence of inferior ST-elevation myocardial infraction. He underwent primary percutaneous coronary intervention via radial approach. Following the procedure he developed swelling at the access site and a bruit was heard. Ultrasonography demonstrated an arteriovenous fistula. He was managed conservatively and was seen few weeks later with complete resolution of his symptoms.

Keywords: Radial artery; Arteriovenous fistula; Angiography
\end{abstract}

\section{Case Report}

A 79-year-old male with cardiac risk factors including hypertension and ongoing smoking presented to the emergency department with chest pain and subsequently found to have an inferior ST elevation myocardial infarction. He was advanced for primary percutaneous coronary intervention (PCI) via right radial approach using a 6-French radial sheath, Judkins Right (JR) 3.5 and Judkins Left (JL) 4 catheters without complications. His angiogram demonstrated a heavily calcified 95\% culprit lesion involving the proximal left circumflex which was treated successfully with a bare metal stent. His access site was assessed few hours later and he was found to have mild swelling and a bruit was heard on auscultation.

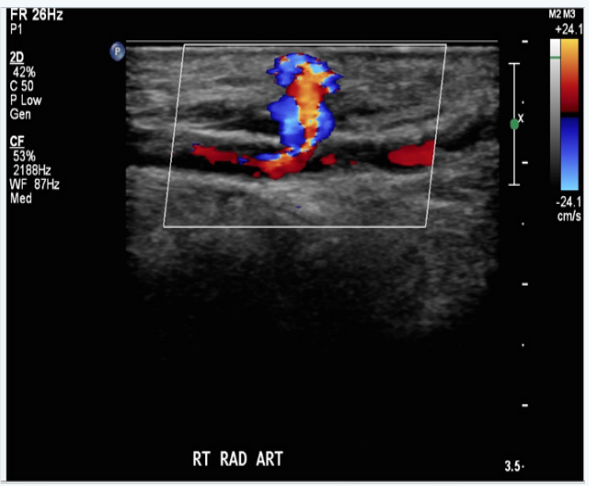

Figure 1: Color Doppler ultrasound demonstrating the presence of arteriovenous fistula at the radial puncture site.

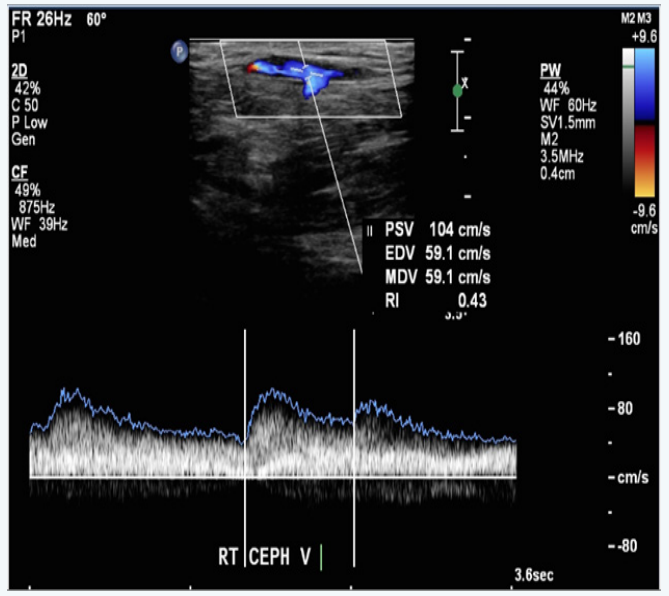

Figure 2: Arteriovenous fistula with low resistance arterialized waveform on color Doppler ultrasound.

Ultrasonography (Figure 1 \& 2 ) demonstrated an arteriovenous fistula (AVF) between the right radial artery and the right cephalic vein, which demonstrated a low resistance arterialized waveform with a velocity of $143 \mathrm{~cm} / \mathrm{s}$. He was managed conservatively as he was asymptomatic. When seen in follow up, his bruit was no longer heard on auscultation.

\section{Discussion}

Transradial coronary angiography has significantly reduced access site complications. AVF is an abnormal connection 
between the arterial and venous systems. AVF is an extremely rare complication following the transradial approach and has been reported only in few cases [1-4]. On the other hand, AVF is a well-known complication of the transfemoral approach. The diagnosis is usually made by color Doppler ultrasonography.

Treatment options may include surgical repair, endovascular intervention, ultrasound guided compression and conservative treatment. The majority of reported cases have been treated surgically, one case with endovascular intervention [4] and one case treated conservatively [2]. There is no consensus regarding the preferred treatment option however. To our knowledge, this is the second case of iatrogenic radial AVF, which was treated successfully in a conservative fashion. This case highlights conservative therapy as a reasonable alternative to surgical therapy in selected patients with iatrogenic radial AVF.

\section{References}

1. Goldberg A, Tsipis A, Rosenfeld I (2013) Arteriovenous fistula after cardiac catheterization from a radial approach. Isr Med Assoc J 15(6): 313-314.

2. Görgülü S, Norgaz T, Sahingöz Y (2013) A case of radial arteriovenous fistula during coronary angiography. Anadolu Kardiyol Derg 13(2): 181-182.

3. Yang JH, Gwon HC, Park JE, Song YB (2012) Arteriovenous fistula of the wrist after transradial coronary intervention. Heart Lung 41(2): 203-206.

4. Sugahara T, Azuma M, Nakashima K, Ito K, Suzuki R, et al. (2013) Postcatheterization radial arteriovenous fistula: balloon-assisted direct percutaneous embolization with N-butyl cyanoacrylate and $50 \%$ glucose solution in two sessions. Jpn J Radiol 31(7): 505-510.

\section{Your next submission with Juniper Publishers will reach you the below assets}

- Quality Editorial service

- Swift Peer Review

- Reprints availability

- E-prints Service

- Manuscript Podcast for convenient understanding

- Global attainment for your research

- Manuscript accessibility in different formats

( Pdf, E-pub, Full Text, Audio)

- Unceasing customer service

Track the below URL for one-step submission https://juniperpublishers.com/online-submission.php 